\title{
Implementation of Lesson Study for Learning Community (LSLC) and PMRI in Three-Dimensional Learning at A State Secondary School in South Sumatera
}

\author{
Rini H. Rusiyanti ${ }^{1, *}$ Ratu I. I. Putri ${ }^{1,}$ Zulkardi Zulkardi ${ }^{1}$ \\ ${ }^{1}$ Department of Mathematics Education, Faculty of Teacher Training and Education, University of Sriwijaya, \\ Indonesia \\ *Corresponding author.Email: rini.herlina.r@gmail.com
}

\begin{abstract}
Lesson Study for Learning Community (LSLC) is one of the efforts that can be done to improve teacher learning abilities. LSLC is an activity that can solve problems faced by teachers by applying various methods or appropriate learning strategies according to the demands of the 2013 curriculum and 21st century skills. PMRI of Indonesian Realistic Mathematics Education is a learning approach that is associated with real things or real situations that have been experienced by students so that the role of PMRI strongly supports the implementation of LSLC. The method used is descriptive qualitative research. While data collection is done by observation, documentation, field notes, and lesson plan and students' worksheet. This research was conducted on eleventh grade students at a state secondary school in South Sumatra Indonesia with the subject matter of three dimensions. There are four stages of LSLC; Plan, Do, See, and Re-design, and the teacher designs the lesson plans and worksheets based on PMRI. The media used is student worksheet. The results of this study indicate that learning with the application of PMRI-based LSLC can help students understand the concept of three-dimensional material, can build good collegiality between mathematics teachers, can solve problems faced by teachers, implementation of learning is in favor of students, and teachers gain experience about learning with PMRI based LSLC.
\end{abstract}

Keywords: Lesson Study for Learning Community, PMRI, Three Dimensional Space, $21^{\text {st }}$ century skills.

\section{INTRODUCTION}

Mathematics can be called Queen as well as Servant for other sciences. Mathematics is said to be a servant because mathematics is a basic science that underlies and serves other sciences. Almost all branches of science that can be studied in this world make mathematics a mandatory requirement before entering the science deeper. While mathematics is said to be the queen because the development of mathematics does not depend on other sciences. Mathematics is the main subject that students must learn since they are in elementary school. Mathematics education in elementary school is the beginning of starting a child to explore his ability to understand concepts in mathematics and the knowledge gained will greatly influence him at the next level of education [1].
Geometry is one of the main materials studied in learning mathematics. Three-dimensional geometry is a part of geometry that discusses geometric shapes such as cubes, pyramids and so on, as well as discussing abstract objects such as points, lines, and fields. These objects are obtained through the process of abstracting concrete objects in everyday life [2]. To study the shape of the space students are faced with objects that are abstract. Our five senses will not be able to perceive the presence of points, lines, edges, diagonal planes, space diagonals, diagonal planes, etc. [3]. Three-dimensional geometry learning should be carried out by carrying out manipulation activities of spatial objects or real objects (concrete experience), brainstorming (parable concepts) until finally students will have abstract knowledge about three-dimensional geometry [4] or in other words linking learning to everyday life. But in reality, teachers teach 
Three-Dimensional material using conventional learning accompanied by assignments. Students feel bored and bored with the way the material is presented by the teacher so that the material conveyed by the teacher is not fully absorbed by the students [5]. Some teachers also still use the lecture and question and answer method in learning activities of three-dimensional material [6]. The learning process in the classroom is also more directed to the ability of students to memorize information, the student's brain is forced to remember and hoard various information without being required to understand the information it remembers to connect it with and daily life [7].

In mathematics learning based on PMRI and using the LSLC system or stages, it is the right approach that can be applied in learning three-dimensional geometry. Widodo (2014) mentions that in learning with the PMRI approach, students are invited to think about how to solve problems that are often experienced by students in everyday life because students are invited to relate and involve the environment around real experiences that students have experienced [8]. Reffers in Putri [9] describes the characteristics of PMRI, including: 1) using contextual problems (phenomenological exploration or the use of contexts), 2) using models (the use of models or bridging by vertical instruments), 3) appreciating the variety of answers and student contribution (the use of students own), 4) interactivity (the interactive character of the teaching process or interactivity) and 5) integrated with other learning topics (the intertwining of various learning strands). Putri (2011) mentions four stages of LSLC, namely; Plan, Do, See and Re-Design, where each stage is designed using the characteristics of PMRI. This is in accordance with the demands of the 2013 curriculum [9].

The 2013 curriculum in its development is supported by various policies developed nationally, one of which is 21 st Century Competence. Students are required to have 21 st century competencies that are realized through the 4Cs which include communication, collaboration, critical thinking, and creativity, this is designed with the PMRI approach [10]. Collaboration strategies can be applied in learning with the LSLC stages carried out by teachers to realize maximum student competencies. Lesson Study for Learning Community (LSLC) is not a learning method or strategy, but lesson study activities can apply various learning methods or strategies that are appropriate to the situation, conditions, and problems faced by teachers [11]. There are four stages of lesson study, namely: "Plan-Do-See-ReDesign" [12]. In the Plan stage, all teachers design lesson plans and student worksheets with the PMRI approach, then Do is the stage where the teacher teaches models in the classroom according to the learning tools that have been compiled together at the plan stage, at this stage, students will be asked to collaborate with friends -friends in the group. Learning with this collaboration will be able to help solve the problems that have been described above. In the See stage, all teachers reflect on discussions about the weaknesses that have been carried out and recorded. ReDesign is the stage where all the results of the weaknesses found in the See stage are redesigned in the lesson plans and student worksheets. So that students will master the concept of the Three Dimensions holistically through learning with PMRI-based LSLC stages.

\section{METHODS}

The method used is descriptive qualitative. While data collection is done by observation, documentation, field notes, designing lesson plans and student worksheets. This research was conducted on students of a state secondary school A state secondary school in South Sumatra in Palembang, Indonesia class XII with the subject matter of Three Dimensional Space. This research was conducted according to the stages of LSLC using the PMRI approach according to its characteristics. There are two instruments developed, the first is an instrument to see the characteristics of PMRI in lesson plans and student worksheets, the second instrument is developed to see teacher learning during the "Do" stage. All instruments are validated first by experts.

\section{RESULTS AND DISCUSSION}

There are four stages in the LSLC, namely: Plan, Do, See, Redesign in collaboration with five PMRI characteristics, namely: phenomenological exploration or the use of contexts, the use of models or bridging by vertical instruments, the use of students owns, the interactive character of the teaching process or interactivity, the intertwining of various learning strands.

\subsection{Plan Stage}

In the Plan stage, the teacher together makes learning tools which include lesson plans, student worksheet for Sharing Task, student worksheet Jumping Task, PMRIbased evaluation questions, and observation sheets that are in accordance with learning with LSLC and PMRI. The following is an overview of the implementation of the Plan stage at a state secondary school in South Sumatra.

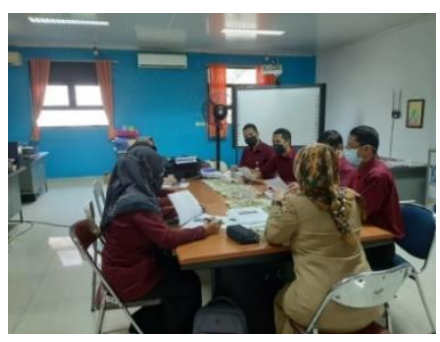

Figure 1 Implementation of the Plan Stage. 
Figure 1 shows several teachers who are members of the Mathematics Subject Teacher Group at the South Sumatra State High School together discuss and make the required learning tools. The purpose of implementing the Plan stage is to produce designs and learning tools that are suitable for students. In addition, this stage also aims to build good collaboration between teachers in the group.

The results of this stage are: 1) Samari, S.Pd is determined as model teacher, 2) Learning is carried out in 1 meeting with an allocation of $2 \times 30$ minutes, 3) 1 question is made for the student worksheet Sharing Task, 1 question is for the student worksheet Jumping Task. , and 3 questions for evaluation in accordance with LSLC and PMRI learning 4) Form groups for class students consisting of 32 students into 8 groups.

\subsection{Do Stage}

In the Do stage, research is focused on learning in the classroom. The model teacher is tasked with leading learning in accordance with the principles of LSLC, namely student-focused learning. While the other teachers served as observers who oversaw observing students during the learning process by taking videos and filling out observation sheets that had been prepared at the Plan stage. Class XII which consists of 32 students is divided into several groups consisting of the remaining 4 ( 2 male students and 2 female students). The seats are made to form a Letter- $\mathrm{U}$ with the middle and front blanks to make it easier for the model teacher to pay attention to students. Students are arranged to sit alternately between boys and girls. In one group of students, there are 1 to 2 teachers on duty as observers.

Learning begins with the model teacher distributing student worksheet Sharing Tasks to students. In this process, all students in the group are allowed to discuss in finding the right answer. The model teacher is tasked with encouraging students to bring out the characteristics of PMRI. This will lead to good collaboration between students. Next, one of the groups is asked to present the results of their group's work in front of the class.

After the presentation, the teacher distributed the student worksheet Jumping Task which contained questions about jumping from the previous question. In this process, students are allowed to ask their group friends for help by mentioning the keyword "Please, teach me". Students who are asked for help may only teach if other students mention the keywords. Meanwhile, students who do not have problems and are not asked for help must do their student worksheet independently.

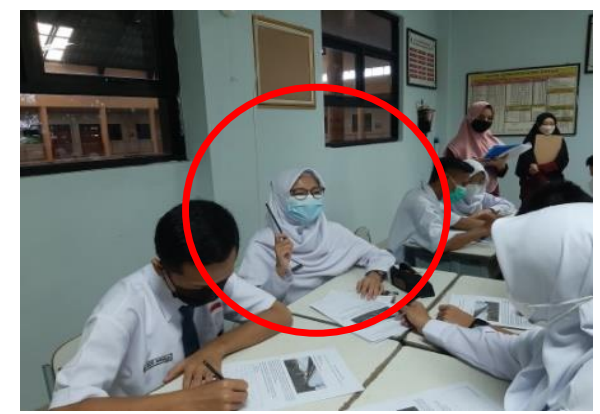

Figure 2 Students who have difficulty in doing student worksheet.

In Figure 2, one can see holding his head which indicates that there is something that makes him uncomfortable, or something that he doesn't understand. Model teachers are expected to understand this situation. So, the model teacher approached the student and asked the student to ask for help to teach other friends in the group.

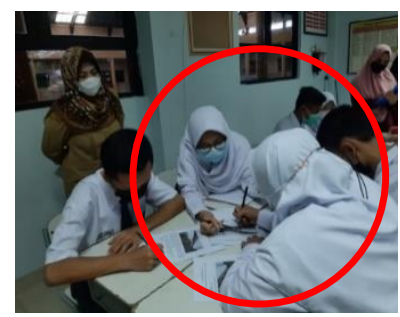

Figure 3 Collaboration and Caring Community happening.

Students who are asked for help must teach their friends until they really understand and can complete the student worksheet given properly. See Figure 3. In this process, it will be seen that students who had problems will issue happy expressions when they really understand the explanation from their friends.

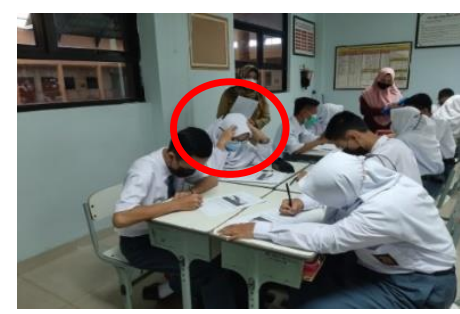

Figure 4 The student's happy expression who was initially troubled. 


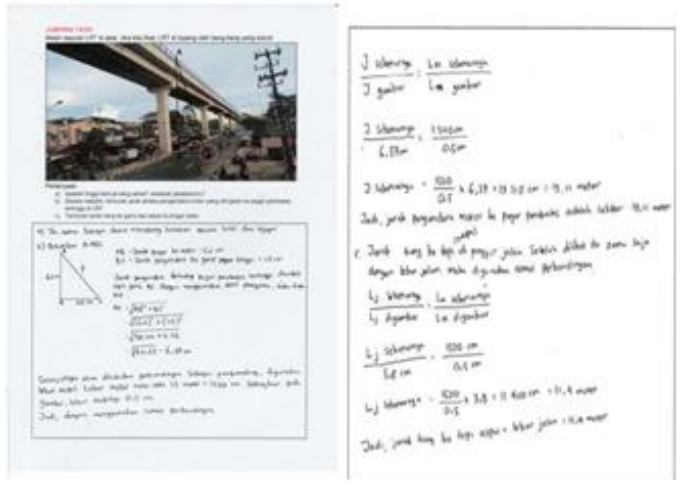

Figure 5 Student worksheet of Jumping Task with students' responses.

In Figure 4 students who had problems and had been taught by their friends were finally able to complete their student worksheet Jumping Task well (Figure 5). This means that a good Collaboration and Caring Community has been formed between students which makes students who initially have problems can finally complete the student worksheet well. After completing the student worksheet of Jumping Task, the teacher asks students to collect their worksheets. And the teacher again asked one of the students to present the answer in front of the class.

Next, the teacher gives an evaluation sheet to the students. When working on evaluation questions, students are not allowed at all to ask questions or give answers to other students. The lesson closed with the model teacher conveying the conclusions of the day's learning.

\subsection{See Stage}

In the See stage, the model teacher and all observers gather in a room to convey the findings in class during the learning process. This stage is opened with the model teacher conveying his impressions, complaints, and difficulties he experienced during the class. Furthermore, the Observer may only convey things about the activities of students in the classroom, who has difficulties or what interesting activities the students do while in class. Observers are also welcome to convey suggestions and messages for model teachers with good language regarding solutions from the findings that have been presented. This will help teachers to be able to design better learning in the future.

\subsection{Re-Design Stage}

At this stage, improvements were made to the lesson plan and student worksheet that were previously designed in the Plan. Improvements were made based on the agreement of the teacher team involved in the implementation of the research. See's results said that there were still students who had difficulty completing the student worksheet Jumping task, the learning method was still not fun, and there were still students who did not want to ask their friends for help to discuss solving the problems given. All weaknesses found in the See results will be redesigned in the next lesson plan and student worksheet according to their weaknesses. So that teacher learning is getting better in the future.

\section{CONCLUSIONS}

Based on the results and discussion, it can be concluded that learning mathematics in threedimensional material, using the LSLC stage and the PMRI approach has a positive impact on teacher learning, such as teachers have designed contextual lesson plans and student worksheet according to the characteristics of PMRI, and this is very in line with the demands of $21 \mathrm{st}$ century learning. The teacher is no longer the center of learning, there is Collaboration and Caring Community during the learning process seen from the discussions held by students in their groups and concern for answering questions asked by their friends through the keyword "Please, teach me", as well as the formation of a good team between Mathematics teacher at A state secondary school in South Sumatera. All of these are stages of LSLC that the teacher does well. The suggestions for future research are: 1) model teachers should be more careful in paying attention to students who are having difficulties, 2) model teachers should introduce the keyword "Please, teach me" before learning begins because not all children are familiar with the culture of asking for help.

\section{REFERENCES}

[1] P. Sari, Pemahaman Konsep Matematika Siswa pada Materi Besar Sudut Melalui Pendekatan PMRI, Jurnal Gantang, 2 (2017) 41-46. DOI: https://doi.org/10.31629/jg.v2i1.60

[2] R. Novita, R. C. I. Prahmana, N. Fajri, and M. Putra, Penyebab kesulitan belajar geometri dimensi tiga, Jurnal Riset Pendidikan, 5(1) (2018) 18-29. DOI: http://dx.doi.org/10.21831/jrpm.v5i1.16836

[3] U. Sari, Farida, F. G. Putra, Pengembangan media pembelajaran berbantuan web dengan pendekatan etnomatematika pada materi ruang sisi datar, National Seminar on Mathematics and Mathematics Education 2017, 2017, pp. 209-214.

[4] C. Browning, A. J Edson, P. Kimani, F. AslanTutak, and PM Kimani "Mathematical content knowledge for teaching elementary mathematics: A focus on geometry and measurement", The Mathematics Enthusiast TME The Mathematics Enthusiast, 11(2) (2014) 333-384. DOI: 10.54870/1551-3440.1306 
[5] D. Wungguli, L. Yahya, Pengaruh Penggunaan Media Berbasis Information and Communication Technology (ICT) terhadap Hasil Belajar Siswa pada Materi Dimensi Tiga, Jambura Journal Of Mathematics Education, 1 (1) (2020) 41-47. DOI : https://doi.org/10.34312/jmathedu.v1i1.5376

[6] D. Dwiranata, D. Pramita, Syaharuddin, Pengembangan Media Pembelajaran Matematika Interaktif Berbasis Android pada Materi Dimensi Tiga Kelas X SMA, Varian Journal, 3(1) (2019) 16. DOI: https://doi.org/10.30812/varian.v3i1.487

[7] L. Ayunigrum, A. P. Kusuma, N. K. Rahmawati, Analisis Kesulitan Siswa dalam Pemahaman Belajar serta Penyelesaian Masalah Ruang Dimensi Tiga, JKPM (Journal of Mathematics Education Studies), 5(1) (2019) 135-142. DOI: http://dx.doi.org/10.30998/jkpm.v5i1.5277

[8] M. S. Widodo, Keefektifan pembelajaran matematika dengan pendekatan pendidikan matematika realistik indonesia (PMRI) pada materi lingkaran di kelas VIII SMP. Indonesian Scientific Journal of Education (Mathedunesa), 3(3) (2014) 125-130.

[9] R. I. I. Putri, Pembelajaran Materi Bangun Datar Melalui Cerita Menggunakan Pendekatan Pendidikan Matematika Realistik Indonesia (Pmri) di Sekolah Dasar, Journal of Education and Learning, 18(2) (2011) 234-239. DOI: http://repository.unsri.ac.id/id/eprint/6798

[10] K. Rahmawati, Pengembangan E-Learning Berbasis Moodle Sebagai Sumber Belajar IPS SMP Kelas VII Sub-Tema Kegiatan Ekonomi Dan Pemanfaatan Potensi Sumber Daya Alam, Thesis. Yogyakarta: Yogyakarta State University, 2016.

[11] F. Umami, TA Kusmayadi, Suyono, Pembelajaran matematika eksperimen dengan model pembelajaran kooperatif tipe jigsaw dengan pendekatan kontekstual berbasis lesson study pada materi bangunan ruang sisi lengkung ditinjau dari gaya belajar siswa kelas IX MTs Negeri Madiun. Journal of Mathematics Learning, 1 (4) (2013).

[12] Sato, Dialogue and collaboration in junior high schools: learning community practice, Japan: JICA, 2014. 